\title{
Exclusion Reloaded: The Chronicles of Covid-19 on Students with Disabilities in a South African Open Distance Learning Context
}

\author{
S.A. Ngubane-Mokiwa* and J.N. Zongozzi
}

\author{
College of Education, University of South Africa, South Africa
}

\begin{abstract}
Students with disabilities have been going through different forms of discrimination and exclusion. These include inaccessible learning materials and learning platforms, negative attitudes from lecturers, fellow students and more. This paper comes from a qualitative study that sought to explore how Covid-19 deepened these educational inequalities at an Open Distance Learning institution in South Africa. The results of the study reveal that institutions of higher learning had to quickly adjust their teaching and assessment to online mode. This led to heightened exclusion of students with disabilities as their examinations had to be postponed to second semester due to lack of preparations for special examinations. Students also reported experiencing extra pressure as they had to write double the examinations at the end of the year. Some students reported lack of access to assistive technologies which they normally borrow from the library, this was because the Post Office was not operating during the National Lockdown Level 5 . The novel nature of Covid-19 is such that the real barriers it caused on people and students with disabilities in particular and it will keep revealing itself gradually. This paper ends by making recommendations on how an ODL institution could accommodate the needs of students with disabilities to enhance their learning experiences during pandemics or natural disasters.
\end{abstract}

Keywords: Learning, Covid 19, Students with disabilities, South Africa.

\section{INTRODUCTION}

In December 2019, the first human cases of Covid19 , which is a disease caused by the novel coronavirus, subsequently named SARS -COV-2 were reported in the City of Wuhan, China [1]. The disease spread rapidly globally. In South Africa, the first case of this disease was reported on the 5th of March 2020 [2], which caused panic among its citizens and politicians. The Covid-19 resulted in many countries imposing strict lockdown regulations to control the movement of people. From a South African perspective, President Cyril Ramaphosa declared a National State of Disaster with countermeasures on March 15 aimed at fighting the wide spread of the virus and buy time to develop and implement a long run response. This was followed by a National Lockdown Level 5 on March 23 which became effective for three weeks from March 27. These weeks were later extended to five weeks until April 30. Public gatherings, travelling, schools, ports of entry, and government events were restricted by the lockdown policies [3].

The imposition of the above lockdown regulations across the globe has had adverse effects on various sectors of the economy, including the higher education sector. According to Tesar [4] of the University of Auckland in New Zealand, Covid-19 took the country's higher education by storm in a way that forced changing the manner in which the sector composes

${ }^{*}$ Address correspondence to this author at the College of Education, University of South Africa, South Africa; Tel: +27123376188;

E-mail: mokiwsa@unisa.ac.za itself, in which staff and students had to change the way they learn and get assessed. Tesar argues, nevertheless, that the disease was a mere catalyst of processes that were put into motion some time ago, rather than a radical change maker. A desktop analysis study leveraging universities and government sources by Crawford et al. [5] provides a timely map of the intraperiod higher education responses to Covid-19 across 20 countries. Their study found diverse responses by higher education institutions from not having a response through to social isolation strategies on campus and rapid curriculum redevelopment for full online offerings.

The above mentioned solution has been the most favoured in the South African higher education context. Mhlanga et al. [6] found that the South African primary, higher and tertiary education sectors unleashed a variety of $4 \mathrm{IR}$ tools in which educational activities switched to remote (online) learning. Although this transition may be expected to be smooth for the University of South Africa (Unisa) as it is an Open Distance Learning (ODL) institution, it is not clear how the Students with Disabilities (SwDs) were catered for. More so because the dedicated unit for SwDs was also closed due to National Lockdown. This concern is further exacerbated by the prevalence of inequalities in South Africa where previously disadvantaged students such as blacks, women, people with disabilities, the rural and urban poor and adults who have missed out on opportunities to access higher education [7], are usually excluded. The Unisa Facts \& Figures Report [8] indicated (without providing reasons) a decrease in enrolment of SwDs on average year-on-year by $9,5 \%$

(C) 2021 Lifescience Global 
since 2012. In 2016, $2321 \quad(0,8 \%)$ SwDs were registered. These students' types of disabilities included the following: communication (talking, listening), emotional (behavioural or psychological), hearing (even with a hearing aid), intellectual (difficulties in learning), physical (moving, standing, grasping), sight and multiple disabilities.

Accessible quality higher education for the above groups of students has been endorsed by various legislation in South Africa. The National Development Plan (NDP) of South Africa Vision 2030 [9] states that "people with disabilities must have enhanced access to quality education and employment. Efforts to ensure relevant and accessible skills development programmes for people with disabilities, coupled with equal opportunities for their productive and gainful employment, must be prioritised" [p.42]. The Constitution of the Republic of South Africa Act 108 of 1996 [10] as well as the Equity and Prevention of Unfair Discrimination Act 4 of 2000 [11] seeks to promote equity by preventing unfair discrimination, thus supports accessible higher education. Furthermore, the White Paper 3 on Higher Education Transformation [12] and the Education White Paper 6: Special Needs Education [13] were approved to ensure equity and redress by eliminating all forms of discrimination based on disability by means of financial support. The Ministry of Education through the National Plan for Higher Education compelled higher education institutions in South Africa to increase access for SwDs by means of their institutional policies, plans and strategies [14]. Such access to higher education for SwDs was recently affirmed in the Strategic Policy Framework on Disability for the Post-School Education and Training System [15]. Equally, the right to education for students with disabilities is provided for in the international instruments like the Article 24 of the Convention on the Rights of Persons with Disabilities (CRPD) [16] which provides that:

States Parties recognize the right of persons with disabilities to education. With a view to realizing this right without discrimination and based on equal opportunity, States Parties shall ensure an inclusive education system at all levels and lifelong learning.

The United Nations Declaration Article 1 [17] on the right to development also states that:

The right to development is an inalienable human right by virtue of which every human person and all peoples are entitled to participate in, contribute to, and enjoy economic, social, cultural and political development, in which all human rights and fundamental freedoms can be fully realized.

In this instance education is a human right that "every human person" like SwDs deserve. South Africa and many other countries are signatories to these international instruments and should always strive to abide by them. The next section presents the research problem that this paper sought to address.

\section{RESEARCH PROBLEM}

SwDs may face greater risks than their nondisabled counterparts in a wide range of aspects during this Covid-19 pandemic. Since the disease thrives in humans with certain underlying health conditions, SwDs face greater health risks, depending on their specific situation. In terms of education, their risk is also higher due to the potentially inaccessible course content and learning platforms [18]. Irrespective of accessibility for SwDs being a constitutional imperative, SwDs in South Africa have been reported as excluded not only at their residences, but also through some arrangements excluding them from fully accessing teaching and learning programmes [19]. In light of these prevailing inequitable practices, alienation and inequalities, it is inevitable [20], it is inevitable to assume that the involuntary transition into full online learning posed by the Covid-19 has worsened the situation especially since higher learning institutions were obliged to swiftly adjust their teaching and assessment to online mode [4]. Such rapid transition could perhaps not afford institutions of higher learning sufficient time to consider the various special needs of the diverse groups of SwDs. Nevertheless, this study sought not to speculate the facts, instead, explore how Covid-19 deepened these educational inequalities in a South African context.

\section{UNIVERSAL DESIGN FOR LEARNING}

Universal design was originated by Architect Ronald Mace in the 1980's to ensure that architecture accommodates the accessibility needs for people with and without disabilities [21]. A common universal design example are the ramps that enable people using wheelchairs, baby strollers and bicycles to gain access to buildings and streets. In the education environment, UDL was adopted with an aim of ensuring 
that the curriculum is accessible to all students including those with disabilities. Perez et al. [22] and Scott et al. [23] posit that UDL allows the students an opportunity to overcome their learning barriers through accommodating all learning needs.

Using UDL to inform learning design assists with ensuring that design and delivery of the course is maximised through emphasising multiple representations of material, varied means for student expression, content and knowledge and multiple ways to motivate and engage student learning [24]). Rose et al. [25] argues that the use of UDL in teaching and learning affords the students affective, strategic and recognition learning networks. It also allows for closing of gaps in prior knowledge, scaffolding, support for learning and facilitates metacognition.

The UDL theoretical framework is grounded on three principles; which is to support recognition learning through multiple flexible methods of presentation (i.e., what is this?), support strategic learning by providing multiple, flexible methods of expression (i.e., How am I going to do that?) and support effective learning by providing multiple, flexible methods of presentation (i.e., Why should I learn this?) [26]. The UDL framework promotes a holistic approach to curriculum development [21] and cultural variability [27].

The UDL framework can also reduce barriers for culturally diverse students and increase the learning opportunities for all students and help them develop proficiency in a broader range of expressive, analytic and cognitive styles important for academic success [27]. Research shows that educators who use the UDL framework to help them design courses could identify clear goals aligned with the instructional practices [24]. In addition, students could positively engage in courses. UDL is divided into different means; which is means of engagement, means of representation and means of action and expression.

\section{Means of Engagement}

This means of engagement requires UDL to be used in such a way that it provides students varied choices of learning approaches that support set learning outcomes and objectives. Ralabate [28] stresses the importance of ensuring that all learning environments have authentic learning and different levels of support. The use of ICT to engage, learn and apply the acquired skills is crucial for students with disabilities. Ralabate [28] emphasizes the importance of self-regulation in order to engage meaningfully.

\section{Means of Representation}

Ralabate [28] discusses this principle by expanding the task of provision of multiple means of representation through making use of ICT to customise the way information is displayed. This involves the provision of alternative representation through auditory information for the SwBs and visual information for the students with hearing impairment. In the case of language and symbols used there should be proper definition of vocabulary and symbols used, whilst mathematical and scientific language ICT can be used to decode and clarify key concepts [28]. It is also important that learning content be presented in such a way that it activates prior knowledge, emphasises critical features and the way they relate to the learning outcomes, and enhances meaning-making and the practical application of knowledge or skill [28].

\section{Means of Action and Expression}

In the case of SwBs one has to think carefully about the activities the student should perform as part of learning. Ralabate [28] postulates that the tasks to be performed, the way the student is expected to navigate around the learning environment and the way in which he or she is going to make use of ICT needs to be considered carefully. It is also essential to ensure that students have good command of their communication, composition and problem-solving tools $[29,28]$

\section{LITERATURE REVIEW}

The literature emphasizes a need for equitable and inclusive Covid-19 control measures worldwide. Such commitment to inclusion, according to Berger et al. [30], means responding to the Covid-19 disease in a manner that is sensitive to the most vulnerable groups, including the homeless, the unemployed and those without adequate insurance, communities of color, indigenous communities, migrants, people with disabilities, and certain frontline healthcare workers as well as other emergency services workers.

Inclusive education entails a system which acknowledges that all children and youth can learn, and that in order to do so, they require support. In doing so, such a system embraces student diversity and recognizes learning as taking place in different social contexts, including universities. The inclusive education system aims to establish education 
structures/systems and methodologies that make it possible for universities to fulfil the needs of all students irrespective of their background, and to enhance their participation in the culture and curricula of centres of learning. Therefore, inclusive education "challenges attitudes, behaviours, teaching methodologies, teaching environments, and curricula to meet the needs of all learners, and to develop learners' strengths such that they are able to participate critically in the learning process" $[31$, p. 6]. From a higher education perspective, especially with regards to SwDs, such inclusion relates to accessible learning material among other things. In terms of accessibility to learning material, previous studies warn that such accessibility need to be considered from two interrelated aspects, namely; content and platform accessibility [32].

\section{Inclusive Learning Content for Students with Disabilities}

Zongozzi [33] who emphasized the need for ODL institutions to implement the policy of granting access to and support for SwDs, identified inaccessible learning material for SwDs at a South African ODL institution as a major barrier towards quality higher education for such students. Such challenges, nevertheless, seem to be a worldwide conundrum, even in first world countries. Soudien [34] argues that SwDs are obvious victims in American higher learning. The author shares a quote from an email by Pamela Joy Lumagabas, from inside a consultancy called Cardinal Learning of California, which, in relation to education for SwDs during Covid-19, states that "(s)tudents with learning disabilities are being abandoned by the education system. Their normal cadre of specialists that have helped them in the past are no longer able to tend to their needs".

While it may be expected by some ODL institutions to swiftly transit to full online learning as compelled by the emergence of the virus, developing and delivering online learning materials that are engaging has been a global challenge. Special considerations are needed especially in activities such as laboratory activities which need to approximate a hands-on experience, making it even an extremely difficult task for those catering for SwDs as these may, at the very least, necessitate implementation of inclusion of access services like interpreters and captionists [35]. Adding to the above challenges, lack of capacity by lecturers to support SwDs in terms of developing and delivering inclusive online learning materials is also reported [33].

In a discussion on inclusive instruction and design for health science lectures, Peterson [36] argues that flexibility in higher education during this Pandemic, in which course design and instruction are strategically planned to ensure full access to course curriculum for students from diverse backgrounds, is key. Her sentiments centres around the assessment of SwDs in terms of which she argues that such assessments need to measure the achievement of the student with a disability, not the disability itself. However, this is probably easier said than done. For most higher education institutions, the sudden emergence of the virus necessitated a quick and unplanned transition to full online learning platforms. Considering the already existing institutional barriers to inclusive learning for SwDs, it may be difficult to fulfil Peterson's standards. Such barriers, as also identified by the lecturers interviewed in Svalina and Ivic [37], include lack of experience, lack of teaching assistance, lack of additional teaching aids and specific materials, as well as lack of specific lecturer's training for lecturing in the contemporary inclusive environment.

Nevertheless, some higher education and learning institutions reported successful implementation of their inclusive learning policies for SwDs. One such institution, as reported in Osman [38], is the Sultan Qaboos University through its provision of the following assistive technologies for SwDs: NVda screen readers, Index Everest v5, Natiq Reader, Braille display, OCR software for PDF reading, Text to speech software, and etc. Furthermore, the University's Disability Unit compelled instructional adjustments in the online course for visually impaired students. This involved consideration of the following design guidelines for transferring courses to the online platforms: uploading only PDF files exported from a word document, and avoiding the use of PDF files that have been prepared through scanning a printed document, providing a textual description for any uploaded graphics, overlaying captioning or speech when using videos that present text on the screen, reading aloud when presenting written text in a recorded lecture, avoiding the usage of tables for designing the layout of a document, instead, only use tables for structuring some sections that require tabular presentation, and using accessible Meeting or Video software with voice over on Apple and NVDA or Microsoft Windows by course instructors.

\section{Inclusive Digital Learning Platforms for Students with Disabilities}

A Covid-19 rapid-response survey of 98 countries around the world discovered that higher learning institutions began teaching online through a variety of 
platforms such as television and radio broadcasting of lessons, and putting in place innovations such as socially distancing proof hubs and centers [39].

Findings from a study examining the experiences of UIN Sunan Kalijaga SwDs in navigating online learning during the COVID-19 found that, most students prefer conventional face-to-face learning as opposed to online learning. The various reasons for such preference included the following; high costs of access to the internet, inaccessible learning systems with respect to online learning platforms and activities. As a result of these challenges and the absence of support these students normally receive from the university's disability office, SwDs sought help from family members, peers, and lecturers [40]. A case study of urban youth with disabilities under Covid-19 in Ethiopia shows that because institutions of higher learning were a place wherein SwDs interact with people and spent happy time, the transition into online learning platforms through TV and not radio, and via Telegram, affected many of the youth in the studied sample as they were unable to access virtual education. Even though some did have access to television at home, the fact that lessons at this level are all provided in English, and English not being their first language, meant that in the absence of being able to ask questions following the content was often too difficult. For student with visual impairments, the medium of instruction presented further challenges as some of the content relied on visual interaction [41].

Although, contrary to the above, Srinivasan [42] reported online learning platforms such as Zoom and video conferencing as useful and effective for electronic learning for SwDs, another paper [43], conversely, demonstrates the adverse impact of lack of practical training. Pacheco et al. [43] further argued that lack of access to electronic devices for SwDs as a result of institutional budgetary constraints, especially since most SwDs come from socioeconomically disadvantaged backgrounds, meant that most of the students were unable to access online classes.

In addition to the emotional stress faced by virtually every human resident on earth due to the Covid-19, Krishnan et al. [44] found that, with respect to their education, students with hearing impairment faced challenges relating to hearing devices, disruptions to comprehend lessons and lack of familiarity with online devices. Thus, social and teaching presence were hampered since their social interaction skills towards others were distracted during the pandemic. The lack of social presence would, therefore, imply that SwDs are not able to project themselves socially and emotionally during this pandemic. Whereas, lack of teaching presence implies exclusive design, facilitation, and direction of cognitive and social processes for the purpose of realising personally meaningful and educationally worthwhile learning outcomes, out of favour of SwDs [45].

\section{RESEARCH METHODOLOGY}

It is widely accepted that Covid-19 has changed how we work. There is no exception in the way we conduct academic research. This research study is part of a bigger study that aims at using narrative research to understand the learning experiences of students with disabilities in the Open Distance e-Learning context. Ethical clearance was granted under the College of Graduate Studies and Permission to conduct research on students so as to improve practice was granted by the Unisa Research Ethics Office. In order to contain the spread of the virus, specific social distancing protocols in line with the Coronavirus (Covid-19) regulations had to be observed. Likewise, the University of South Africa [46] published a Covid-19 Position Statement on Research Ethics which had serious implications on the research methods followed. The document compels a responsible approach to human participant, community engaged, animal, environmental, molecular and cell research in the context of COVID-19. While the university supports the continuation of research activities, through this document face-to-face or studies with an inherent risk to participants and/or researchers were restricted for the duration of the lockdown period during which this study was conducted. Nevertheless, this study's methodology was largely guided by the principles embodied in the above-mentioned position statement.

This study which focused on the experiences of SwDs with respect to access to learning materials and platforms at Unisa (largest ODL institution in Africa), was qualitative in nature. The inclusion criteria involved SwDs who were registered for the 2020 academic year. Such information was obtained through the Unisa Disability Unit as well as the Student Admissions and Registrations Directorate. In total, 6000 SwDs were found to be registered for 2020 , of which data was subsequently collected from about 10 students with disabilities, divided into 6 students and 4 leaders of students with disabilities who always deal directly with students' concerns. This group of students positively responded to the initial invitation to participate. Initially, 
data collection was scheduled to occur through face-toface interviews with participants. However, the Covid19 guidelines in relation to social distancing as prescribed in the position statement mentioned above, compelled the use of alternative means of collecting data. Subsequently, in-depth interview questions were sent to the participants through emails. In doing this, the authors of this paper considered the potential constraints to participation because of inability to access email content, depending on the nature of their disability and sense of agency. Hence, these students were strongly encouraged to seek assistance from peers and family members in accessing and responding to the emails. Nevertheless, participants detailed and submitted their views through the email and WhatsApp method.

The resulting data were analysed by means of thematic analysis. In accordance with Castleberry et al. [47], this analysis method proved to be adequate since it allowed the identification, analysis and reporting of themes. The written narratives from participants were read several times by the authors in order to increase their sense of familiarity with the texts. Subsequently, line-by-line coding was used to generate tentative descriptive labels for each line of transcript data to ensure careful consideration of each text and to provide a basis for the researcher to identify emerging analytical categories and broader [47].

\section{FINDINGS}

The findings of the study will be presented in a thematic manner. This will be supported by extracts from the participants.

\section{Online Learning and Assessment Excludes those who are Digitally Illiterate}

When the universities pronounced the use of full online learning for teaching and assessment, it was meant to bridge the gap caused by lockdown and social distancing regulations. But the findings on the ground reveal that students that use Braille and Large print had no other way of carrying on with their education. The views below indicate that these students do not have computer literacy and online learning skills. The students stated that:

"We do not oppose the use of online learning, but my question is: What will happen to us who cannot use the computer? What will happen to those who do not have access to internet?" (Male student with visual impairment).

"I have always been coming to our Disability Unit to get my Large print learning material and I get the same for my exams. Now, how did the university think I was going to learn without that service? How was I supposed to be computer literate all of a sudden?" (Female student with visual impairment).

The above concerns can be exacerbated by a number of issues, namely; most SwDs come from socioeconomically disadvantaged backgrounds [43], nature of disability as a hindrance [18], prevalence of inequitable practices, alienation and inequalities that exclude SwDs [20], and high internet costs [40]. Without adequate measures and resources in place, the above categories of students are likely to either fail or dropout if no support towards accessing online learning and assessment is thoroughly provided.

\section{No Respect for Human Dignity}

The issue of Social Constructions is always topical when dealing with matters of marginalised communities. When people have a negative perception of people with disabilities, they tend to mistreat them through hurtful words and actions. Some might argue that these are caused by lack of awareness about disability, but it is a fact that whether intended or not they violate the rights and personhood of students with disabilities. The students narrated the following experiences which make them feel violated:

"I have to present my doctor's note at every point in order to get the required assistance. It is so humiliating to have to expose your medical details to everyone just so you can be accommodated. Why, why do we have to move around with our medical files just to get our right to education?" (Female Postgraduate student with mobility disability -uses crutches).

"One of the invigilators refused me to use a computer to type my examination. As a student with dyslexia I had to be insulted and told that I want to copy when I asked to be accommodated due to my dyslexia. They told me to use DAISY which I have 
never used before, I only saw for the firsttime during exams" (Female student with dyslexia).

"Whenever we ask to be reasonably accommodated, the invigilators say: Do you think you are special? Why do you have to always ask for special treatment? I tell them I am not special, but I have special needs that need to be accommodated for me to learn effectively. I think the invigilators have not been sensitized to the needs of students with disabilities" (Female student with quadriplegia).

It is expected for university staff to have prior knowledge of registered SwDs in order to provide relevant support. Nevertheless, unsurprisingly, the above views reaffirm Zongozzi [33] that lack of clear procedures to identify SwDs at the Unisa is one of the main barriers towards quality higher education for such students. Zongozzi [33] further states that since support of students is a quality imperative within a human rights approach to quality higher education, such insensitivity as the one presented above, may as well be regarded as contravention of human rights and dignity.

\section{Inadequate Time to Complete Online Summative Assessment}

Online assessment is designed in such a way that when the prescribed lapses the system goes off on its own. Adjusting the time to accommodate a person with disability according to their specific need requires the Information and Communication Technology (ICT) personnel to make such a modification per student. With lockdown regulations keeping the staff members away from campus and requiring multiple clearances in order to enter campus, most of these modifications could not be made. The students narrated that:

"Whenever I am doing my online examinations, I do not get enough time to type my examinations! When I ask the invigilator, she said I should stop seeking for attention." (Female student with Dyslexia)

"Doing online examinations is a nightmare as the timing of the exam does not take specific disability into consideration. This means that if the exam is three hours, it will go off when that time lapses, there is no extra time for a blind person who is using audio format to listen to the questions and type using assistive technology" (Female student with blindness).

The above views contrast the suggestion by Peterson [36] for flexibility in higher education during this Pandemic wherein course design and instruction are strategically planned to ensure full access to course curriculum for students from diverse backgrounds. This is, however, expected as assessment plans at Unisa are usually captured a year prior to the actual academic year. The novel nature of the Covid-19 and the forced transition into full online mode [4] probably did not afford the university time to consider Peterson's recommendations. This also emphasizes lack of experience, lack of teaching assistance, as well as lack of specific lecturer's training for lecturing in the contemporary inclusive environment [37], as major barriers to inclusive education during this pandemic.

\section{Systemic Challenges}

It was apparent that there were ICT related systemic challenges which ranged from inadequate hardware and software provisions, aesthetic design that takes no consideration of the needs of students with disabilities. Though Unisa has always been an ODeL university, research done by Ngubane-Mokiwa [49] reveals that the students have always complained about the inaccessibility of the ICT platforms. Covid-19 exacerbated this challenge. The students expressed the following views:

"Unisa websites need improvement to accommodate students with disabilities. For example, they could have audio rendering for blind students and text captioning for the deaf students." (Male student with Blindness)

"I had to submit an assignment with attachments. The online system could not take more than 1 gigabyte. I kept trying to upload my documents, but they were too heavy for the online submission system. The university needs to adjust the systems to the new Covid-19 issues" (Male student with partial sight). 
The above comments are a reiteration of the sentiments shared earlier by Lynn et al. [35] that special considerations such as the implementation of inclusion of access services like interpreters and captionists in certain circumstances are necessary. The above views, though, also add to the growing concern reported worldwide that current online learning platforms in response to Covid-19 are not sufficient for inclusive education in favour of SwDs [40, 41, 43, 44]

\section{Inability to Access Learning Material in Different Formats}

The imposition of lockdown regulations meant that even the post office could not operate as there was no one to deliver the goods. It also posed a challenge for blind students who use Braille which needs them to touch the document, so there was a need for online learning that comes in multiple accessible formats. The findings on the ground reveal that students with different disabilities could not access their learning material in accessible formats which excluded them further from teaching and learning.

The student stated that:

"Like in my case, I am doing LLB and I always receive my study material two weeks before examination. Rather than that, lecturers tend to use diagrams to illustrate, this totally excludes us the blind students as we cannot see diagrams" (Male LLB student with blindness)

There is a need for Unisa to adapt best practices from the Sultan Qaboos University. Such practices as reported earlier in Osman [38], include instructional adjustments in online courses for SwDs, including the following design guidelines for transferring courses to the online platforms: uploading only PDF files exported from a word document, and avoiding the use of PDF files that have been prepared through scanning a printed document, providing a textual description for any uploaded graphics, overlaying captioning or speech when using videos that present text on the screen, reading aloud when presenting written text in a recorded lecture, avoiding the usage of tables for designing the layout of a document, instead, only use tables for structuring some sections that require tabular presentation, and using accessible Meeting or Video software with voice over on Apple and NVDA or Microsoft Windows by course instructors.

\section{Lack of Digital Skills to Use Assistive Technologies}

There is a misconception that because a student has a disability, they know how to use assistive technologies. This assumption disregards the fact that someone could be newly disabled and still learning the new way of doing things while also dealing with the pain of losing their 'normalcy'. This means that they still have to go to colleges like Optima College to learn how to lead a life as a person with a disability. For this groups of students, the lockdown complicated their life further as they now had to be isolated and never got an opportunity of acquiring the required digital skills. The students related that:

"There are some of us who recently
became disabled and we have no
knowledge of assistive devices and how
they can enable our access to education".
(Female student with paraplegia).
"For some of us who became disabled
during the course of the year, there are no
assistive devices that are provided by
NFSAS. These tools are expensive! Leave
alone the fact that we cannot even use
them efficiently" (Male student with
blindness).

This is another example of the prevalence of inequitable practices, alienation and inequalities that exclude SwDs [20]. Perhaps Casazza [50] was correct in saying that ' $[a] c c e s s$ without the appropriate support is a false opportunity'. In order to ensure fair and inclusive access to higher education, SwDs ought to be provided adequate training on the use of assistive technologies during the orientation phase rather than retrospectively, in response to Covid-19.

\section{STEM Field Meant for Non-Disabled Students Only}

The field of Science, Technology, Engineering and Mathematics is a practical field that requires a lot of innovation and consideration of UDL principles to reasonably accommodate students with disabilities. The students expressed their sadness at the university not accommodating students with disabilities at the Science campus. They stated that:

"As a student of Engineering who started my course before I acquired my disability, I feel very excluded in the science 
campus. The Labs are not designed to cater for students with disabilities! Since I am now quadriplegic, I must be lifted by people in order to get to the $2^{\text {nd }}$ floor of the Programming Labs as they are only accessible through the stairs. Equally, if you are partially-sighted you won't be able work in those labs as the instructions are in small print" (Female student with mobility disability).

"Work Integrated Learning (WIL) programmes require students to avail themselves at workplaces for practical experience. Given the fact that most institutions are still weary of accommodating SwDs where students find themselves struggling to get themselves to the company they are assigned to. We have to part with a lot of money to get accessible accommodation near the workplace. I had to move from my comfort zone in order to get closed to the WIL space. We need more support in this regard" (Male student with blindness).

Earlier in this study, Lynn et al. [35] raised a need for special considerations in activities such as laboratory activities which need to approximate a hands-on experience, making it even an extremely difficult task for those catering for SwDs as these may, at the very least, necessitate implementation of inclusion of access services like interpreters and captionists. Indeed, the views by participants show this to be the case within the Science, Technology, Engineering and Mathematics (STEM) disciplines at Unisa. Findings such as the above probably result from institutional budgetary constraints preventing the provision of adequate access to electronic devices for the necessary simulation that will provide SwDs practical experience approximate to a hands-on [43], thus granting them the right to full participation and equalisation of opportunities in all sectors of development [51].

\section{CONCLUSION}

This paper sought to understand the learning experiences of students with disabilities during the Covid-19 National Lockdown. Conducting the electronic interviews and collecting the WhatsApp messages revealed that the students with disabilities faced challenges such as: exclusion due to being digitally illiterate, lack of respect for human dignity, inadequate time to complete online summative assessment, systemic challenges, inability to access learning materials in different formats, lack of digital skills to use assistive technologies and STEM field being meant for non-disabled students only. Engaging with different literature highlighted different challenges that students faced due to Covid-19 and how these challenges were mitigated. We unpacked Universal Design for Learning with an aim of indicating the principles that should guide the design of accessible learning environments. Although the study was conducted on a limited scope, the results herein can be used to guide future studies to deeply understand the extent of the pandemic. It is therefore our recommendation that more detailed research be conducted, the universities need to adopt an integrated approach to supporting students with disabilities so that stakeholders can work together to improve their learning experience. The invigilators need to be trained on how to deal with students with disabilities in both online and physical examination settings. The learning and assessment design team should involve students with disabilities in testing learning platforms so as to avoid barriers in online learning.

\section{REFERENCES}

[1] World Health Organisation. Coronavirus disease 2019 (COVID-19) Situation Report - 94. Available from: https://www.who.int/docs/default-source/coronaviruse/ situation-reports/20200423-sitrep-94-covid-19.pdf [Accessed $23^{\text {rd }}$ September 2020]

[2] Mukandavire Z, Nyabadza F, Malunguza NJ, Cuadros DF, Shiri T, Musuka G. Quantifying early COVID-19 outbreak transmission in South Africa and exploring vaccine efficacy scenarios. PLoS ONE 2020; 15(7): 1-11. https://doi.org/10.1371/journal.pone.0236003

[3] Arndt C, Davies R, Gabriel S, Harris L, Makrelov K, Robinson S, Levy S, Simbanegavi W, van Seventer D, Anderson L. Covid-19 lockdowns, income distribution, and food security: An analysis for South Africa. Global Food Security 2020; 26: 1.5 . https://doi.org/10.1016/j.gfs.2020.100410

[4] Tesar M. Towards a Post-Covid-19 'New Normality?' Physical and Social Distancing, the Move to Online and Higher Education. Policy Futures in Education 2020; 18(5): 556-559. https://doi.org/10.1177/1478210320935671

[5] Crawford J, Butler-Henderson K, Rudolph J, Malkawi B, Glowatz M, Burton R, Magni PA, Lam S. COVID-19: 20 countries' higher education intra-period digital pedagogy responses. Journal of Applied Learning \& Teaching 2020; 3(1): 9-28. http://journals.sfu.ca/jalt/index.php/jalt/index

[6] Mhlanga D, Moloi T. COVID-19, and the Digital Transformation of Education: What Are We Learning on 4IR in South Africa? Educ Sci 2020; 10(7): 1-11. https://doi.org/10.3390/educsci10070180

[7] Ntshoe I. The political economy of public-private good of open, distance, higher education institutions in South Africa. Acta Academica 2011; 43(3): 83-106. https://hdl.handle.net/10520/EJC15536 
[8] The University of South Africa. An Institutional Profile: Unisa Facts \& Figures Report. Pretoria. Available form: https://www.unisa.ac.za/sites/corporate/default/About/Facts\&-figures [Accessed $10^{\text {th }}$ October 2020].

[9] National Planning Commission. National Development Plan 2030: Our future - make it work. Available from: https://www.gov.za/sites/default/files/gcis_document/201409/ ndp-2030-our-future-make-it-workr.pdf - [Accessed $10^{\text {th }}$ October 2020].

[10] South Africa. Constitution of the Republic of South Africa Act No. 108 of 1996.

[11] South Africa. Equity and Prevention of Unfair Discrimination Act No. 4 of 2000.

[12] South Africa. White Paper 3 on Higher Education Transformation. 1997.

[13] South Africa. Education White Paper 6: Special Needs Education. 2001.

[14] Ministry of Education. National plan for higher education. Available from: https://www.dhet.gov.za/HED\%20Policies/ National\%20Plan\%20on\%20Higher\%20Education.pdf [Accessed $10^{\text {th }}$ October 2020].

[15] Department of Higher Education and Training. Strategic policy framework on disability for the post-school education and training system. Available from: https://www.dhet.gov.za/ SiteAssets/Gazettes/Approved\%20Strategic\%20Disability\%2 OPolicy\%20Framework\%20Layout220518.pdf [Accessed 10 October 2020]

[16] United Nations. Convention on the Rights of Persons with Disabilities. Available from: https://www.un.org/disabilities/ documents/convention/convoptprot-e.pdf [Accessed $10^{\text {th }}$ October 2020].

[17] United Nations. Declaration on the Right to Development. Available from: https://www.ohchr.org/en/professionalinterest/ pages/righttodevelopment.aspx [Accessed $10^{\text {th }}$ October 2020].

[18] Zhang $H$, Nurius $P$, Sefidgar $Y$, Morris $M$, Balasubramanian S, Brown J, Dey AK Kuehn K, Riskin E, Xu X, Mankoff J. How Does COVID-19 impact Students with Disabilities/Health Concerns? arXiv Online, 2020. Available from: https://arxiv.org/ftp/arxiv/papers/2005/2005.05438.pdf [Accessed October 01 2020].

[19] Mutanga O. Inclusion of Students with Disabilities in South African Higher Education. International Journal of Disability, Development and Education 2018; 65(2): 229-242. https://doi.org/10.1080/1034912X.2017.1368460

[20] Ndlovu S. Access into professional degrees by students with disabilities in South African higher learning: A decolonial perspective. African Journal of Disability 2019; 8(0): 1-12. https://doi.org/10.4102/ajod.v8i0.514

[21] Messinger-Willman J, Marino MT. Universal design for learning and assistive technology: Leadership considerations for promoting inclusive education in today's secondary schools. NASSP Bulletin 2010; 94(1): 5-16. https://doi.org/10.1177/0192636510371977

[22] Perez L, Gulley A, Prickett L. Improving Access to Higher Education with UDL and Switch Access Technology: A Case Study. In Empowering Learners with Mobile Open-Access Learning Initiatives 2017; pp. 13-30. https://doi.org/10.4018/978-1-7998-1213-5.ch025

[23] Scott L, Temple P. A Conceptual Framework for Building UDL in a Special Education Distance Education Course. Journal of Educators Online 2017; 14(1): 48-59. https://files.eric.ed.gov/fulltext/EJ1133749.pdf

[24] Smith FG. Analyzing a college course that adheres to the Universal Design for Learning (UDL) framework. Journal of the Scholarship of Teaching and Learning 2012; 12(3): 3161. https://scholarworks.iu.edu/journals/index.php/josotl/ article/view/2151
[25] Rose DH, Gravel JW. Universal design for learning. In Peterson P, Baker E, McGraw B. (eds.) International Encyclopedia of Education. Oxford: Elsevier 2010; pp. 119124.

[26] Rose DH, Meyer A. A Practical Reader in Universal Design for Learning. Cambridge, MA: Harvard Education Press 2005.

[27] Chita-Tegmark M, Gravel JW, De Louredes M, Serpa B, Domings $\mathrm{Y}$, Rose $\mathrm{DH}$. Using the universal design for learning framework to support culturally diverse learners. Journal of Education 2019; 192(1): 17-22. https://doi.org/10.1177/002205741219200104

[28] Ralabate PK. Universal Design for Learning: Meeting the Needs of All Students. Available from: https://floridarti. usf.edu/resources/pl_modules/intensive_interventions/day1/ UDL\%20Article.pdf [Äccessed 1 October 2020].

[29] Bocconi S, Ott M. ICT and Universal Access to Education: Towards a Culture of Accessibility. In Lytras MD, Ruan D, Tennyson RD, Ordonez De Pablos P, García Peñalvo FJ, Rusu L. (eds.) Information Systems, E-learning, and Knowledge Management Research. Berlin, Heidelberg: Springer; vol 278. https://doi.org/10.1007/978-3-642-35879-1 39

[30] Berger ZD, Evans NG, Phelan AL, Silverman RD. Covid-19: control measures must be equitable and inclusive. The British Medical Journal 2020; 368: 1-2. https://doi.org/10.1136/bmj.m1141

[31] Ntombela $\mathrm{S}$. The progress of inclusive education in South Africa: Teachers' experiences in a selected district, KwaZuluNatal. Improving Schools 2011; 14(1): 5-14 https://doi.org/10.1177/1365480210390082

[32] Ngubane-Mokiwa SA. Accessibility strategies for making MOOCs for people with visual impairments: a universal design for learning (UDL) perspective. Available from: http://oasis.col.org/handle/11599/2561 [Accessed October 01 2020].

[33] Zongozzi JN. Accessible Quality Higher Education for Students with Disabilities in a South African Open Distance and e-Learning Institution: Challenges. International Journal of Disability, Development, and Education 2020: 1-13. https://doi.org/10.1080/1034912X.2020.1822518

[34] Soudien C. Complexities of difference and their significance for managing inequality in learning: Lessons from the COVID-19 crisis. Springer 2020; 1-9. https://doi.org/10.1007/s11125-020-09486-x

[35] Lynn MA, Templeton DC, Ross AD, Gehret AU, Bida M, Sanger II TJ, Pagano T. Successes and Challenges in Teaching Chemistry to Deaf and Hard-of-Hearing Students in the Time of COVID-19. Journal of Chemical education 2020; (97): 3322-3326. https://doi.org/10.1021/acs.jchemed.0c00602

[36] Peterson $\mathrm{KH}$. Inclusive instruction and design for health science lectures. Disability Compliance for Higher education 2020; 26(2): 2-3.

https://doi.org/10.1002/dhe. 30900

[37] Svalina V, Ivic V. Case Study of a Student with Disabilities in a Vocational School during the Period of Online Virtual Classes due to Covid-19. World Journal of Education 2020; 10(4): 115-123

https://doi.org/10.5430/wje.v10n4p115

[38] Osman ME. Global impact of COVID-19 on education systems: the emergency remote teaching at Sultan Qaboos University. Journal of Education for Teaching 2020: 1-9. https://doi.org/10.1080/02607476.2020.1802583

[39] Reimers FM, Schleicher A. A framework to guide an education response to the COVID-19 pandemic of 2020 . Available from: https://www.hm.ee/sites/default/files/frame work_guide v1_002_harward.pdf [Accessed 30th September 2020]. 
[40] Ro'fah R, Hanjarwati A, Suprihatiningrum J. Is Online Learning Accessible During COVID-19 Pandemic? Voices and Experiences of UIN Sunan Kalijaga Students with Disabilities. Nadwa: Jurnal Pendidikan Islam 2020; 14(1): 138.

https://doi.org/10.21580/nw.2020.14.1.5672

[41] Emirie G, lyasu A, Gezahegne K, Jones N, Presler-Marshall $\mathrm{K}$, Tilahun K, Workneh F, Yadete W. Experiences of vulnerable urban youth under covid-19: the case of youth with disabilities. Gender and Adolescence: Global Evidence. Covid-19 Series. Available from: https://www.researchgate. net/publication/344510154 Experiences of vulnerable urba n_youth_under_covid-19_the_case_of_youth_with disabilities [Accessed October 01 2020].

[42] Srinivasan DK. Medical students' perceptions and an anatomy teacher's personal experience using an e-learning platform for tutorials during the Covid-19 crisis. Anat Sci Educ 2020; 13(3): 318-319. https://doi.org/10.1002/ase.1970

[43] Pacheco LF, Noll M, Mendonça CR. Challenges in Teaching Human Anatomy to Students with Intellectual Disabilities During the Covid-19 Pandemic. Anatomical Sciences Education 2020; 13(5): 556-557. https://doi.org/10.1002/ase.1991

[44] Krishnan IA, Mello GD, Kok SA, Sabapathy SK, Munian S, Ching HS, Kandasamy P, Ramalingam S, Baskaran S, Kunan VN. Challenges Faced by Hearing Impairment Students During COVID-19. Malaysian Journal of Social Sciences and Humanities (MJSSH) 2020; 5(8): 106-116. https://doi.org/10.47405/mjssh.v5i8.472

[45] Garrison DR. Online community of inquiry review: Social, cognitive and teaching presence issues. Journal of Asynchronous Learning Networks 2007; 11(1): 61-72. https://doi.org/10.24059/olj.v11i1.1737
[46] The University of South Africa. Unisa COVID-19 position statement on research ethics. Available from: https://staff.unisa.ac.za/file_source/intranet/Content/News $\% 2$ 0\&\%20Communications/E-Notices/Documents/UnisaCOVID-19-position-statement-research-ethics14April2020.pdf [Accessed October 01, 2020]

[47] Castleberry A, Nolen A. Thematic analysis of qualitative research data: Is it as easy as it sounds? Currents in Pharmacy Teaching and Learning 2018; 10(6): 807-815. https://doi.org/10.1016/j.cptl.2018.03.019

[48] Zongozzi JN, Sefora S, Ngubane-Mokiwa S. Opening up education through academic support for Students with Disabilities. Available from: http://oasis.col.org/bitstream/ handle/11599/3298/PCF9_Papers_paper_222.pdf?sequence =4\&isAllowed=y [Accessed October 01 2020].

[49] Ngubane-Mokiwa SA. Information and communication technology as a learning tool: Experiences of students with Blindness. Available from: http://hdl.handle.net/10500/13246 [Accessed 23 ${ }^{\text {rd }}$ October 2020].

[50] Casazza ME. Harvard Symposium 2000: Developmental Education: Who are and where did we come from? Journal of Developmental Education 1999; 23(1): 2-7. http://www.jstor.org/stable/42775015

[51] Adjei-Amoako Y. Promoting inclusive development in Ghana: Disabled people's and other stakeholders' perspectives. Development in Practice 2016; 26(7): 865-875. https://doi.org/10.1080/09614524.2016.1210092

[52] White GW, Summers JA. People with disabilities and community participation. Journal of Prevention \& Intervention in the Community 2017; 45(2): 81-85. https://doi.org/10.1080/10852352.2017.1281041

https://doi.org/10.6000/2292-2598.2021.09.01.17

() 2021 Ngubane-Mokiwa and Zongozzi; Licensee Lifescience Global.

This is an open access article licensed under the terms of the Creative Commons Attribution Non-Commercial License (http://creativecommons.org/licenses/by-nc/3.0/) which permits unrestricted, non-commercial use, distribution and reproduction in any medium, provided the work is properly cited. 